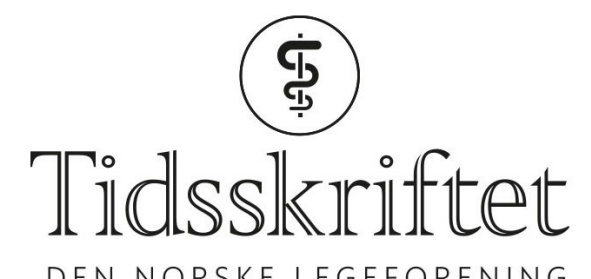

DEN NORSKE LEGEFORENING

\title{
En god innføring i immunologi
}

ANMELDELSER

ELLEN MATHEA KIRSCH WARLO

Lege, Vestre Viken, Drammen sykehus

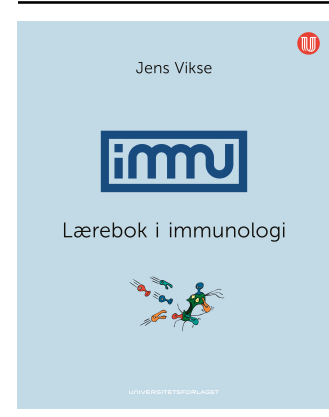

Jens Vikse

IMMU

Lærebok i immunologi. 131 s, tab, ill. Oslo: Universitetsforlaget, 2019. Pris NOK 349

ISBN 978-82-15-03522-2

IMMU er en lærebok med 16 tilhørende videoforelesninger tilgjengelig på nett. Den er rettet mot medisinstudenter og er ment å gi en oversikt over faget immunologi. Boken fungerer like bra som repetisjon for en nyutdannet lege, og helt sikkert også for mer erfarne leger som ønsker en oppfriskning.

Læreboken er inndelt i 16 kapitler som tar for seg ulike deler av immunforsvaret. Den er kort og konsis, men allikevel detaljert. Innholdsfortegnelsen er ryddig, og det er lett å finne frem til det man lurer på. Forfatteren har skrevet boken i notatform med punkter og tabeller. Til hvert kapittel er det en tilhørende videoforelesning som utfyller og forklarer konseptene i teksten. Det oppfordres til å bruke bok og video parallelt, noe jeg kan være enig i, særlig hvis man ikke kan så mye immunologi fra før.

Det er rikelig med gode illustrasjoner i boken. Forfatteren har fått hjelp til å illustrere de ulike immuncellene av Holman, og resultatet er blitt veldig godt og morsomt. Figurene gjør det mye lettere å forstå notatformatet og immunologi generelt. Det samme designet brukes gjennom hele boken, noe som gir et fint helhetsinntrykk. Skulle jeg pirke på noe, ville jeg ønske meg enda høyere oppløsning på noen av illustrasjonene.

Kombinasjonen av bok og nettressurs er en god idé. Nettressursen er bedre enn mange av forelesningene jeg har vært på, men ikke like underholdende som formatet til andre internasjonale nettressurser som f.eks. Osmosis. Uansett er den god, og jeg tror mange vil ha glede av denne ressursen. 
Alt i alt har forfatteren laget en fin og forståelig bok som jeg veldig gjerne skulle ha hatt da jeg studerte. Den er relevant for pensum og inneholder temaene som undervises på medisinstudiet. Dersom du foretrekker å lese sammenhengende tekst, er kanskje ikke dette boken for deg. Men for meg var den et supert tilskudd til bokhylla!

Publisert: 16. mars 2020. Tidsskr Nor Legeforen. DOI:10.4045/tidsskr.20.0036

(C) Tidsskrift for Den norske legeforening 2020. Lastet ned fra tidsskriftet.no 